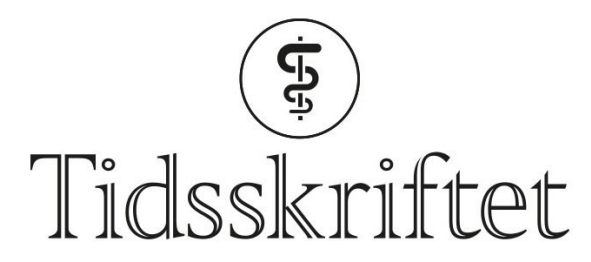

DEN NORSKE LEGEFORENING

\title{
Neste generasjon tumordiagnostikk?
}

FRA ANDRE TIDSSKRIFTER

RUTH HALSNE

Tidsskriftet

Kunstig intelligens kan brukes til å anslå prognosen ved kreft på grunnlag av bildemateriale fra tumorsnitt.

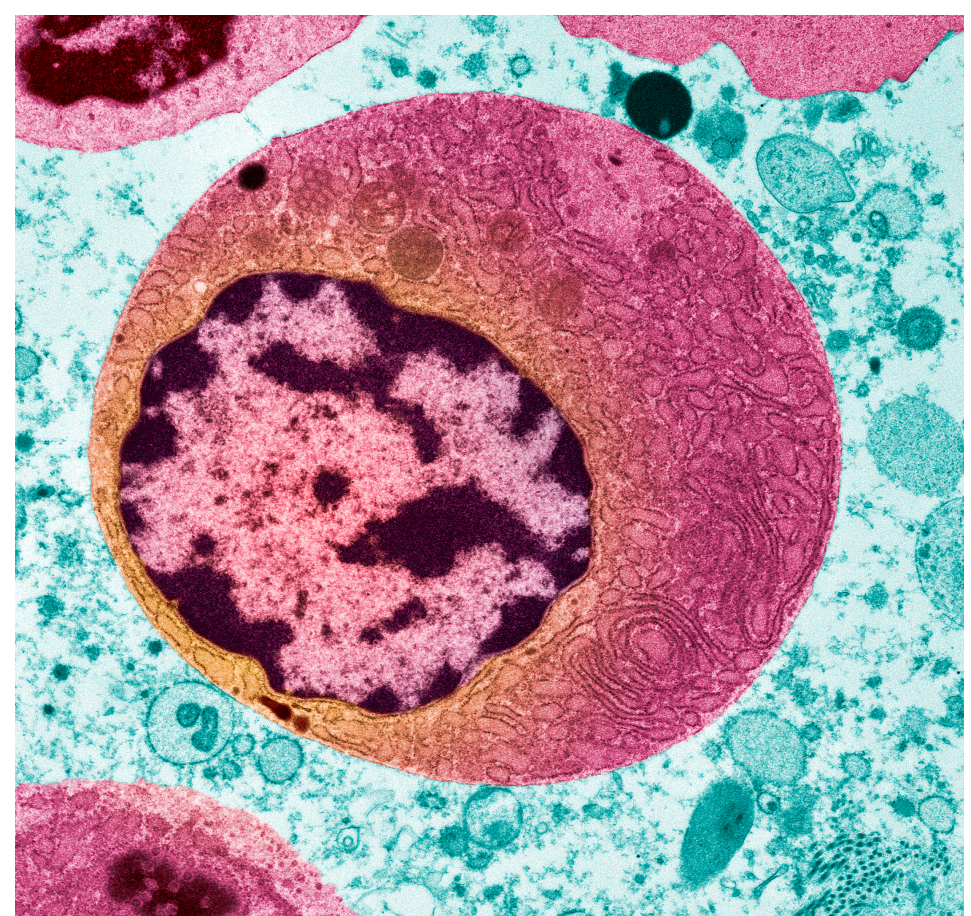

Transmisjonselektronmikroskopbilde av kreftcelle tatt med 4 ooo gangers forstørrelse viser kjernen (mørk) med kromatin (rosa). Illustrasjonsfoto: Science Photo Library/ NTB scanpix

Kromatinets organisering i tumorceller blir vurdert ved morfologiske analyser. I en studie publisert i tidsskriftet The Lancet Oncology har forskere brukt maskinlæring til automatisk gjenkjenning av kromatinorganisering for å definere og validere en prognostisk biomarkør (1).

Over 400 ooo bilder av cellekjerner fra tumorceller med Feulgen-farget DNA ble brukt til dyp læring av kromatinorganisering. Ved bruk av såkalt nukleotyping ble kromatinorganiseringen klassifisert som enten heterogen eller homogen. Heterogen organisering ble ansett som unormal. Deretter ble denne biomarkøren validert i seks pasientkohorter med ulike krefttyper. I alle kohortene fant man at pasienter med kromatinheterogene tumorer hadde dårligere prognose for overlevelse enn pasienter med kromatinhomogene tumorer. 
- Ved histologisk undersøkelse av maligne svulster gjøres det alltid en histologisk gradering og en angivelse av grad av kjerneatypi og heterogenitet, forteller Wenche Reed, som er patolog og leder av forskningsavdelingen ved Stab forskning, innovasjon og utdanning ved Oslo universitetssykehus.

- Den histologiske graderingen sier noe om tumorens evne til vekst og spredning. Forskerne bak denne studien har gjennom avansert digital bildediagnostikk og enorme datamengder fra et stort antall kreftprøver utviklet en maskinell algoritme for vurdering av kjerneatypi, kalt nukleotyping. Styrken ved denne studien er at metoden er testet ut på større pasientkohorter, i tillegg til at den er testet ut retrospektivt på ulike karsinomer og sarkomer, sier Reed.

Gjennom nukleotyping ble tumoren klassifisert som kromatinhomogen eller -heterogen, noe som er en viktig prognostisk faktor. Det var en svak korrelasjon mellom kromatinorganisering og histologisk grad og mikrosatellittinstabilitet, men kromatinorganiseringen ga mye sikrere prognostisk informasjon enn sistnevnte.

- Mye tyder på at denne metodikken kan bidra til en enda mer presis gradering av svulsters aggressivitet, og at den kan bli et viktig supplement i den diagnostiske histopatologiske undersøkelsen av kreftsvulster og dermed gi bedre grunnlag for valg av behandling, sier Reed.

\section{LITTERATUR:}

1. Kleppe A, Albregtsen F, Vlatkovic L et al. Chromatin organisation and cancer prognosis: a pan-cancer study. Lancet Oncol 2018;19:356 - 69. [PubMed][CrossRef]

Publisert: 21. desember 2018. Tidsskr Nor Legeforen. DOI: 10.4045/tidsskr.18.0830

(C) Tidsskrift for Den norske legeforening 2020. Lastet ned fra tidsskriftet.no 